\title{
Penanggulangan Stunting Melalui Modal Sosial di Desa Besmarak Kecamatan Nekamese Kabupaten Kupang
}

\author{
${ }^{1}$ Nursal am, ${ }^{2}$ Mel kisedek N.B.C. Neolaka, ${ }^{3}$ William Djani, ${ }^{4}$ Hendrik Toda \\ 1,2,3,4 Program Studi Administrasi Nega ra, Fakultas Ilmu Sosial dan Ilmu Politik,Universitas Nusa \\ Cendana Kupang, Nusa Tenggara Timur \\ Korespondensi: nursalamjeppu@yahoo.com
}

\begin{abstract}
Abstrak: Stunting merupakan salah satu masalah publik yang perlu mendapat perhatian dan penanganan. Kejadian stunting jika dibiarkan dapat berimplikasi terhadap kualitas sumber daya manusia, yaitu disamping berisiko pada hambatan pertumbuhan fisik dan kerentanan anak terhadap penyakit, juga menyebabkan hambatan perkembangan kognitif yang a kan berpengaruh pada tingkat kecerdasan dan produktivitas anak di masa depan.

Pengabdian pada masyarakat (PPM) yang dilakukan dalam bentuk penyuluhan di desa Besmarak kecamatan Nekamese kabupaten Kupang diharapkan memberikan pengetahuan kepada masyarakat bahwa pemecahan masalah stunting tidak hanya melalui bantuan perbaikan Kesehatan dan gizi yang diberikan oleh pemerintah, namun juga dapat melalui modal sosial masyarakat yaitu melalui jaringan sosial dan norma kepercayaan masyarakat.Terdapat hubungan yang kuat antara modal sosial dan penyelesaian berbagai masalah publik sehingga masyarakat dengan modal sosial yang lebih tinggi juga memiliki kepedulian yang lebih tinggi, mereka mampu mengambil tindakan bersama dalam melakukan pencegahan stunting.
\end{abstract}

Kata Kunci : Stunting, Jaringan Sosial, Norma Kepercayaan, Gotong Royong

\begin{abstract}
Stunting is one of the public problems that need attention and handling. The incidence of stunting if left unchecked can have implications for the quality of human resources, namely in addition to risking physical growth barriers and children's vulnerability to disease, it also causes cognitive development barriers that will affect children's intelligence and productivity levels in the future. The community service (PPM) which is carried out in the form of counseling in Besmarak village, Nekamese sub-district, Kupang regency is expected to provide knowledge to the community that solving the stunting problem is not only through health and nutrition improvement assistance provided by the government, but also through community social capital, namely through social networks and community trust norms. There is a strong relationship between social capital and solving various public problems, so that people with higher social capital also have higher awareness, they are able to take collective action in preventing stunting.
\end{abstract}

Keywords: Stunting, Social Networks, Trust Norms, Mutual Cooperation

\section{PEN DAHULUAN}

Stunting atau biasa disebut kerdil, di kalangan anak-anak masih tetap menjadi masalah kesehatan utama yang belum terselesaikan. Stunting disebabkan oleh banyak faktor seperti kondisi sosial ekonomi, gizi ibu saat hamil, kesakitan pada bayi, dan kurangnya asupan gizi pada bayi. Balita stunting di masa yang akan datang akan mengalami kesulitan dalam mencapai perkembangan fisik dan kognitif yang optimal. Stunting memiliki implikasi biologis untuk perkembangan otak dan fungsi neurologis yang diterjemahkan menjadi gangguan kognitif ${ }^{1}$. Kejadian stunting sering menimpa anak yang berusia di bawah lima tahun (balita), anak yang tergolong stunting, dicirikan secara fisik yaitu panjang atau tinggi badannya berada di bawah minus dua standar deviasi dari pada anak yang seumurnya ${ }^{2}$.

Masalah stunting akan berimplikasi banyak jika sejak dini tidak diberikan pemecahan, sehingga pemerintah memandang stunting adalah masalah serius bagi pembangunan nasional, khusus bidang Kesehatan. Berbagai upaya pencegahan stunting telah dan akan dilakukan serta merupakan prioritas nasional dalam program pembangunan Kesehatan, yaitu meliputi percepatan pengurangan kemiskinan, peningkatan pelayanan kesehatan dan gizi masyarakat, pemerataan layanan pendidikan berkualitas, peningkatan akses terhadap perumahan dan pemukiman layak, serta peningkatan tata kelola layanan dasar 3

This is an open-access artide under the CC BY 4.0 International

License Idea PengabdianMasyarakat (2021)

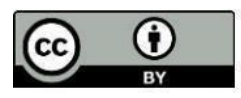

OPEN 
Pencegahan masalah stunting juga menjadi bagian tujuan Pembangunan Berkelanjutan (SDGs) khususnya tujuan 2 "Tanpa Kelaparan" yang telaah diadopsi oleh pemerintah. Pelaksanaan SDGs menekankan pada prinsip no one left behind (tidak ada yang tertinggal) sebagai bagian dari hak asasi manusia untuk menjamin tidak terjadinya diskriminasi dan secara spesifik memberikan perhatian khusus kepada kelompok masyarakat rentan atau miskin ${ }^{4}$.

Kekerdilan pada anak merupakan masalah yang membutuhkan penanganan serius karena berkontribusi besar pada penurunan kualitas sumber daya manusia, dikhawatirkan sumber manusia Indonesia di masa depan mengalami kemunduran dan kualitasnya tertinggal dari bangsa lain. Anak-anak dapat mencapai potensi pertumbuhan mereka jika mereka diasuh di lingkungan yang sehat dan pengasuh mereka mengikuti praktik kesehatan, nutrisi, dan perawatan yang direkomendasikan ${ }^{5}$.

Jumlah anak di desa Besmarak yang menderita stunting sebanyak 24 anak sedangkan secarakeseluruhan di kabupaten Kupang terdapat 4.750 atau $15,32 \%^{6}$. Berdasarkan data ini secara nasional kabupaten Kupang memang masih berada di bawah rata-rata nasional yaitu 30,8\%, namun provinsi Nusa Tenggara Timur berada diberada di atas angka stunting nasional yaitu sebanyak $52.46 \%$. Penanganan masalah stunting merupakan tanggung jawab pemerintah melalui berbagai kebijakan termasuk melakukan kegiatan sosialisasi untuk meningkatkan pemahaman orang tua dan keluarga mengenai pemenuhan kebutuhan gizi dan pola pengasuhan anak yang baik ${ }^{7}$. Salah satu strategi yang diambil dalam penuntasan masalah stunting adalah strategi percepatan perbaikan gizi melalui peningkatan peran masyarakat.

Berkaitan dengan PPM ini, penulis memfokuskan pada strategi penanggulangan stunting dengan peran masyarakat melalui konsep gotong royong sebagai modal sosial. Keterlibatan masyarakat adalah hal yang mendasar karena masyarakat mempunyai potensi sumber daya yang cukup, baik yang berkaitan dengan ide, materi, dan tenaga. Konsep gotong royong identik dengan konsep partisipasi karena di dalamnya ada unsur kesediaan untuk saling terlibat dan membantu satu sama lain tanpa adanya paksaan dalam melakukan suatu aktivitas bersama. Budaya gotong royong ini sesungguhnya bukan hal baru dalam peradaban manusia 8 .

Berdasarkan pendapat ini gotong royong mengandung nilai-nilai luhur dari suatu masyarakat dan digolongkan sebagai modal sosial dalam mengatasi berbagai masalah. Gotong royong adalah juga salah satu bentuk dari solidaritas sosial, sedangkan Solidaritas sosial adalah keadaan saling percaya antar anggota kelompok atau komunitas ${ }^{9}$.

Konsep modal sosial yang digunakan dalam penanggulangan stunting adalah pandangan bahwa modal sosial terdiri dari; jaringan sosial dan norma kepercayaan ${ }^{10}$. Kualitas saling hubungan sosial diantara masing-masing dipengaruhi oleh kapasitas mereka dalam memecahkan persoalan yang mereka hadapi. Oleh karena itu, modal sosial dipahami sebagai suatu sumber untuk tindakan bersama, yang ditujukan untuk mencapai hasil yang lebih besar.

Target luaran yang diharapkan dari kegiatan penyuluhan tentang stunting melalui modal sosial di Desa Besmarak kecamatan Nekamese, adalah:

a. Peningkatan aspek kognisi, afeksi, dan psikomotorik dari audiens tentang jaringan sosial sehingga dapat memperkuat solidaritas sosial masyarakat dalam mengatasi stunting.

b. Peningkatan aspek kognisi, afeksi, dan psikomotorik tentang norma kepercayaan dari audiens sehingga bermanfaat bagi mereka dalam memahami dan menyelami tentang fungsi norma kepercayaan yang berkembang.

This is an open-access artide under the CC BY 4.0 International

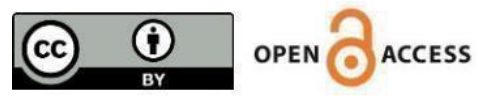


Program pencegahan stunting dilakukan dengan berbagai cara, salah satunya adalah penyuluhan.melakukan penyuluhan kepada masyarakat diharapkan menambah pengetahuan mereka serta mendorong Masyarakat untuk terlibat langsung dalam penanganan stunting ${ }^{11}$.

\section{METODE}

\section{Persiapan}

a. Pengurusan zin pelaksanaan, proses perizinan dimulai dari tingkat provinsi, kabupaten, kecamatan dan desa.

b. Koordinasi dengan kepala desa Besmarak untuk mendapatkan jumlah kepala keluarga yang menjadi target penyuluhan dan persiapan tempat lokasi kegiatan.

c. Koordinasi dengan kepala dusun I, II, dan III untuk mendapatkan informasi tentang anak-anak yang mengalami stunting, agar dihadirkan orang tua mereka dalam kegiatan penyuluhan.

d. Pelaksanaan penyuluhan pada tanggal 24 Oktober 2020, jam 09.00 s/d 15.00 Wita e. Lokasi kegiatan di Gereja Desa Besmarak Kecamatan Nekamese kabupaten Kupang.

f. Bentuk penyuluhan adalah dengan penyampaian materi dan peragaan gambar/liflet tentang masalah stunting dan penanggulangannya melalui modal sosial.

\section{Penyuluhan penanggulangan stunting dengan pendekatan modal sosial}

a. Pemaparan tentang pendekatan gotong royong sebagai modal sosial dalam mengatasi stunting.

b. Pemaparan tentang struktur jaringan sosial

c. Pemaparan tentang norma-norma kepercayaan masyarakat

d. Diskusi tentang peran modal sosial dalam penanggulanagn stunting

\section{Pemaparan Materi yang Terkait Aspek}

a. Kognisi, memberikan pengetahuan tentang peranan modal sosial dalam mengatasi masalah stunting

b. Afeksi, melalui tanya jawab dan diskusi tentang masalah stunting dan penanganannya melalui modal sosial.

c. Psikomotori, melalui peragaan berbagai masalah stunting dan penangannya melalui modal sosial.

\section{Bentuk Partisipasi Mitra}

a. Memfasilitasi ruang pertemuan yang represtatif untuk kegiatan penyuluhan

b. Sebagai audiens dalam ceramah yang bertajuk penanggulangan stunting dengan pendekatan modal sosial c. Terlibat dalam diskusi tentang penanggulangan stunting dengan pendekatan modal sosial.

\section{Evaluasi}

a. Evaluasi program, yaitu penilaian tentang proses persiapan dan pelaksanaan penyuluhan tentang penanggulangan stunting melalui modal sosial

b. Evaluasi Hasil, yaitu penilaian tentang hasil yang dicapai dari kegiatan penyuluhan tentang stunting melalui modal sosial. Metode yang digunakan untuk menilai keberhasilan kegiatan penyuluhan, yaitu dari persentase kehadiran peserta minimal $75 \%$ dari undangan, keaktifan dalam tanya jawab/diskusi, dan kualitas jawaban yang diberikan saat pertanyaan langsung oleh narasumber.

This is an open-access artide under the CC BY 4.0 International

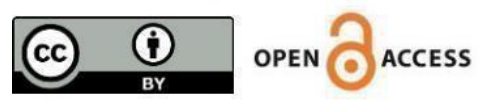




\section{HASIL DAN PEMBAHASAN}

Kegiatan yang dilaksanakan oleh Tim pengabdian kepada masyarakat (PPM) Fisip Undana Kupang adalah melakukan pengabdian dalam bentuk penyuluhan dan diskusi yang berkaitan dengan penanggulangan stunting melalui modal sosial. Kegiatan penyuluhan ini diharapkan dapat memperkuat pemahaman Audiens tentang peranan modal sosial. Topik-topik yang ditampilkan dalam kegiatan penyuluhan adalah:
a. Gotong royong sebagai modal sosial
b. Struktur jaringan sosial
c. Norma-norma kepercayaan masyarakat

Tabel 1: Dimensi Utama Modal Sosial dan Karakteristiknya

\begin{tabular}{|l|l|}
\hline Struktur Hubungan Sosial: Jaringan Kerja & Kualitas Hubungan Sosial: Norma \\
\hline Tipe: & Norm of trust \\
Informal $\leftrightarrow$ formal & - Social trust \\
ukuran/kapasitas: & -keluarga/personal \\
Terbatas $\leftrightarrow$ luas & - digeneralisasi \\
Spasial: & - Kepercayaan sipi/ institusi \\
Rumah Tangga $\leftrightarrow$ Global & Norm of reciprocity \\
Struktural: & - Sejenis vs pengganti \\
terbuka $\leftrightarrow$ tertutup & - Langsung vs tidak langsung \\
rapat $\leftrightarrow$ jarang Homogen & - Cepat vs lambat \\
$\leftrightarrow$ heterogen Hubungan: & \\
Vertikal $\leftrightarrow$ horizontal & \\
Sumber: Diadaptasi dari Stone (2001) &
\end{tabular}

Pemaparan dari tim PPM Fisip Undana tentang penanggulamgan stunting dengan modal sosial telah menjelaskan kepada audiens bahwa budaya gotong royong adalah bagian dari modal sosial. Budaya gotong royong sebagai bagian modal sosial adalah sangat potensial memecahkan masalah karena modal sosial mengandung (1) struktur hubungan sosial atau jaringan sosial, (2) kualitas hubungan sosial atau norma.

Struktur hubungan sosial terdiri unsur-unsur tipe hubungan, ukuran/kapasitas hubungan, ruang hubungan, hubungan struktural, dan arah hubungan. Sedangkan kualitas hubungan adalah menyangkut tentang norma kepercayaan dan norma yang bersifat timbal balik. Modal Sosial sesungguhnya merupakan determinan yang dapat dijadikan sarana efektif mengatasi berbagai masalah publik termasuk masalah stunting. Argumen yang dibangun bahwa modal sosial dapat dipandang sebagai atribut individu dan masyarakat untuk mengkarakterisasi beragam cara yang dapat digunakan oleh para anggotanya dalam berinteraksi satu sama lain.

This is an open-access artide under the CC BY 4.0 International

License Idea PengabdianMasyarakat (2021)

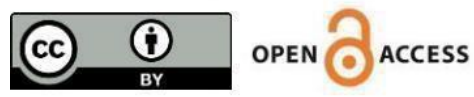



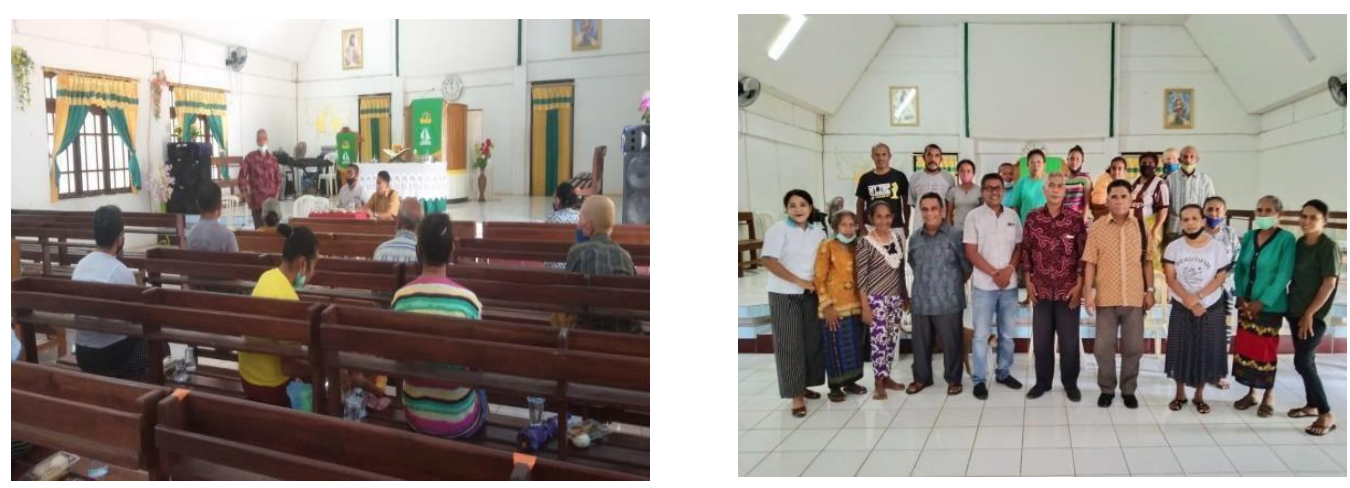

Gambar $1 \& 2$ : Kegiatan Penyuluhan di Desa Besmarak Kec. Nekamese

\section{Evaluasi}

\section{Evaluasi Program}

Evaluasi program PPM diadakan dengan tujuan untuk mengetahui tingkat keberhasilan penyuluhan penanggulangan stunting melalui modal sosial di desa Besmarak kecamatan Nekamese kabupaten Kupang. Adapun indikator dalam mengetahui keberhasilan evaluasi program pengabdian ini adalah:

a. Target peserta kegiatan penyuluhan penanggulangan stunting melalui modal sosial di desa Besmarak kecamatan Nekamese kabupaten Kupang adalah minimal 75\% telah tercapai. Dari 35 peserta yang ditargetkan jumlah yang pendaftar 31 orang.

b. Target kehadiran peserta minimal $75 \%$ dari peserta yang mendaftar telah tercapai. Dalam kegiatan penyuluhan, lebih $75 \%$ jumlah peserta yang hadir dari seluruh sesi kegiatan yaitu mencapai 31 peserta.

c. Kegiatan penyuluhan penanggulangan stunting melalui modal sosial di desa Besmarak kecamatan Nekamese kabupaten Kupang mendapat antusias dan penghargaan yang tinggi dari warga masyarakat. Terjalin suasana keakraban dan silaturahmi antara warga dan tim PPM Fisip Undana Kupang.

Evaluasi Hasil

Tujuan dari evaluasi hasil adalah untuk mengetahui tingkat keberhasilan dari kegiatan penyuluhan. Dialog interaktif antara peserta dan narasumber yang berlangsung secara intensif menunjukkan bahwa peserta memiliki semangat yang tinggi untuk memahami materi yang disampaikan oleh narasumber. Terdapat beberapa pertanyaan yang bersifat substantif dari peserta, antara lain:

a. Peserta mempertanyakan bagaimana cara menilai/mengukur bahwa seorang anak menderita stunting, tindakan apa yang dilakukan jika ada anggota keluarga terindikasi menderita stunting, dan bagaimana cara perawatan terhadap mereka.

b. Peserta mempertanyakan tentang bagaimana jika di desa mereka banyak anak yang menderita stunting,bagimana peran pemerintah Desa.

c. Peserta juga mempertanyakan tentang bagaimana tentang keterlibatan masyarakat melalui gotong royong, apakah seluruh warga diharuskan ikut serta. 
Berdasarkan penilaian evaluasi hasil menunjukkan bahwa kegiatan penyuluhan tentang penanggulangan stunting melalui modal sosial di desa Besmarak kecamatan Nekamese kabupaten Kupang berhasil dilaksanakan dengan indikator:

a. 75\% peserta yang hadir mampu memahami dan mengetahui dengan dengan baik tentang; (a) Apa yang dimaksud dengan stunting; (b) ciri-ciri stunting; (c) jumlah kasus stunting di wilayah mereka dan wilayah lebih lain, yaitu di kabupaten Kupang dan di provinsi NTT; (d) bagaimana peran keluarga dalam mengatasi stunting; (e) bagaimana peran pemerintah; dan (f) bagaimana peran warga masyarakat melalui modal sosial.

b. $75 \%$ peserta yang hadir memahami bagaimana hubungan/jaringan sosial dalam mengatasi stunting.Mereka telah memahami tentang; (a) tipe jaringan sosial, yaitu jaringan formal atau informal; (b) ukuran dan kapasitas jaringan sosial, yaitu kapasitas tinggi atau rendah; (c) ruang dimana jaringan sosial itu berada, yaitu pada rumah tangga dan lingkungan keluarga, dan lingkungan masyarakat; (d) struktural jaringan sosial, yaitu jaringan tertutup atau terbuka, jaringan padat atau jarang, jaringan homogen atau heterogen; dan (e) relasi jaringan sosial, yaitu relasi vertikal atau horizontal.

c. $75 \%$ peserta yang hadir memahami tentang norma Kepercayaan dalam mengatasi stunting di wilayahnya. Mereka telah memahami tentang; (a) kepercayaan tentang nilai sosial; (b) kepercayaan tentang nilai kelembagaan.

\section{KESIMPULAN}

Modal Sosial sesungguhnya merupakan determinan yang dapat dijadikan sarana efektif mengatasi berbagai masalah publik termasuk masalah stunting. Argumen yang dibangun adalah modal sosial dipandang sebagai atribut individu dan masyarakat untuk mengkarakterisasi beragam cara yang dapat digunakan oleh para anggotanya dalam berinteraksi satu sama lain. Berdasarkan konsep dan teori tentang modal sosial maka kejadian-kejadian stunting di desa Besmarak kabupaten Kupang dapat diatasi dengan pendekatan modal sosial masyarakat.

Terdapat korelasi yang kuat antara modal sosial dan penyelesaian berbagai masalah publik sehingga masyarakat dengan modal sosial yang lebih tinggi juga memiliki kepedulian yang lebih tinggi, mereka mampu mengambil tindakan bersama dalam melakukan pencegahan stunting. Permasalahannya adalah bahwa di antara aspek modal sosial yang beragam, perlu diidentifikasi aspek yang mana yang mempunyai peran signifikan dalam memahami serta menumbuhkembangkan kepedulian, pengetahuan, dan tindakan yang diperlukan.

Berdasarkan hasil penyuluhan, maka direkomendasikan agar nilai gotong sebagai salah satu modal sosial senantiasa direvitalisasi melalui berbagai penyuluhan dan tindakan memperkuat solidaritas sosial sehingga meningkatkan solidaritas sosial pada masyarakat.

\section{UCAPAN TERIMAKASIH}

Ucapan terima kasih disampaikan kepada pemerintah kabupaten Kupang, Camat Nekamesa, Kepala Desa Besmarak, warga masyarakat di dusun 1, 2, dan 3 atas dukungan yang diberikan sehingga PPM Fisip Undana dapat terselenggara dengan baik. 


\section{DAFTAR PUSTAKA}

1. Shonkoff.J.F.and D.A. Phillips, (eds) (2000) From Neurons to Neighborhoods: The Science of Early Childhood Development. eric.ed.gov. National Academy of Sciences Press: Washington DC.

2. WHO Multicentre Growth Reference Study Group, 2006., Assessment of differences in linear growth among populations in the WHO Multicentre Growth Reference Study. Acta Paediatrica Supplement 450, 56- 65.

3. Kementerian Kesehatan RI. 2014. Riset Kesehatan Dasar Tahun 2013. Jakarta: Kementerian Kesehatan RI.

4. Direktorat Kesehatan dan Gizi Masyarakat Bappenas, 2018, Pencegahan Stunting dan Pembangunan Sumber Daya Manusia, Buletin Jendela dan Informasi Kesehatan, Kementrian Kesehatan RI, ISSN 2088-270X.

5. Dewey, Kathryn G and Khadija Begum, 2011, Long-term Consequences of Stunting in Early Life Maternal and child nutrition, https://doi.org/10.1111/j.1740-8709.2011.00349.x

6. Rahakbauw, Marthen A, 2019, 4.750 anak di Kabupaten Kupang mengalami kekerdilan,https://www.antaranews.com/berita/1008014/4750-anak-di-kabupaten-kupangmengalamikekerdilan.

7. Masneno,Korinus,2019, 4.750 anak di Kabupaten Kupang mengalami kekerdilan,https://www.antaranews.com/berita/1008014/4750-anak-di-kabupaten-kupangmengalamikekerdilan.

8. Irfan, Maulana, 2016, Metamorfosis Gotong Royong Dalam Pandangan Kontruksi Sosial, Prosiding Seminar Nasional Menuju Masyarakat Indonesia Sejahtera, Fikom UNPAD, Bandung.

9. Lawang. (2005). Kapital Sosial dalam Perspektif Sosiologi. Jakarta: FISIP UI

10.Stone, Wendy, 2001. Measuring social capital : towards a theoretically informed measurement framework for researching social capital in family and community life. Melbourne, Australian Institute of Family Studies.

11.Puspitasari A, Putra WD, Amir H. Pencegahan Stunting Pada Anak Di Desa Tamangapa Kec. Ma'rangKab.Pangkep. Idea Pengabdi Masy. 2021;1(1):05-8. 